\title{
PEMBUANGAN BAYI DALAM PERSPEKTIF HAK ASASI MANUSIA
}

\author{
Ni Nyoman Muryatini \\ Program Studi Sistem Informasi,Institut Teknologi Dan Bisnis STIKOM Bali \\ Email: tiniaryadiputra2016@,gmail.com
}

\begin{abstract}
This study focuses on the disposal of the baby by the biological parents through killing the baby first then discarding. The study aims to find out the crime of child disposal from the perspective of human rights. The method used in this research is normative legal research, which is descriptive analysis to find a rule of law in order to answer the legal issues faced. The results showed that the right to life which is part of human rights has been owned by babies since they were in the womb as God's creatures. No one can take away someone's right to life. The increase in cases in the last three years proves that there is no deterrent effect on the perpetrators of crime. The urgency of making the right legal instrument is needed for perpetrators of child disposal crimes.
\end{abstract}

Keywords: baby disposal, human rights

\begin{abstract}
Abstrak
Penelitian ini dibatasi oleh pembuangan bayi yang dilakukan oleh orang tua kandung, dengan membunuh bayi terlebih dahulu kemudian dibuang. Adapun tujuan dari penelitian ini adalah untuk mengetahui tindak kejahatan pembuangan bayi bila ditinjau dari perspektif hak asasi manusia. Metode yang digunakan dalam penelitian ini adalah penelitian hukum normatif, yang bersifat deskriptif analisis untuk menemukan suatu aturan hukum guna menjawab isu hukum yang dihadapi.Hasil penelitian menunjukkan bahwahak hidup yang merupakan bagian dari hak asasi manusia telah dimiliki oleh bayi semenjak berada di dalam kandungan sebagai mahluk ciptaan Tuhan. Tidak ada seorang pun yang dapat merampas hak hidup seseorang. Meningkatnya kasus dalam tiga tahun terakhir, membuktikan tidak adanya efek jera terhadap para pelaku kejahatan. Urgensi pembuatan instrumen hukum yang tepat diperlukan bagi pelaku kejahatan pembuangan bayi.
\end{abstract}

Kata Kunci :pembuangan bayi, hak asasi manusia

\section{A. Pendahuluan}

Salah satu tujuan dari sebuah pernikahan adalah untuk melanjutkan keturunan. Anak merupakan anugerah yang diberikan oleh Tuhan Yang Maha Esa yang patut untuk kita syukuri. Di 
Jurnal Hukum Saraswati (JHS) Volume. 03, Nomor 02, (2021)

FAKULTAS HUKUM UNMAS DENPASAR

ISSN (Cetak) : 2715-758X ISSN (Online): 2720-9555

DOI:https://doi.org/10.36733/jhshs.v2i2

https://e-journal.unmas.ac.id/index.php/JHS

137

lain pihak masih banyak orang tua yang tidak mensyukuri atas anugerah yang diberikan, dengan membuang bayi yang merupakan darah dagingnya sendiri.Pembuangan bayi merupakan sebuah tindak kejahatan yang menarik untuk dibahas dan perlu mendapatkan perhatian yang serius.

Berdasarkan keterangan $\mathrm{Ni}$ Luh Gede Yastini selaku Pihak Komisi Penyelenggaraan Perlindungan Anak Daerah (KPPAD) Bali, selama kurun waktu tahun 2017 sampai 2020 terdapat 40 kasus pembuangan bayi di Propinsi Bali. ${ }^{1}$ Melihat jumlah kasus pembuangan bayi selama kurun waktu 3 (tiga) tahun terakhir merupakan sebuah fenomena yang sangat memprihatinkan. Pelaku dari pembuangan bayi tidak lain adalah orang tua kandung bayi tersebut. Dalam beberapa kasus bayi yang dibuang tidak sedikit yang ditemukan dalam keadaan meninggal. Pembuangan bayi merupakan tindak kejahatan yang dilakukan dengan perencanaan dan kesengajaan, hal ini dapat dilihat dari tujuan dari

${ }^{1}$ Tribunnews.com, Tercatat 40 Kasus Pembuangan Bayi di Bali, Yang Anyar Ditemukan di Sungai Badung, 21 Januri 2020, diakses pada tanggal 30 Juli 2021 orang tua kandung untuk melepaskan diri dari tanggung jawab terhadap bayi yang dibuangnya. Apapun alasan dibalik perbuatan tersebut, perbuatan ini tidak dapat dibenarkan karena mencederai sisi kemanusiaan dan merupakan sebuah tindak kejahatan.Sangat disayangkan sekali orang tua kandung yang seharusnya menyayangi, bertanggung jawab untuk merawat, menjaga dan melindungi, namun membuang bayi yang merupakan buah hatinya sendiri. Orang tua seharusnya sebagai pihak yang bertanggung jawab untuk merawat dan memberikan perlindungan, karena bayi belum mampu untuk memenuhi kebutuhannya sendiri. Namun dalam kenyataannya justru pihak orang tua melepaskan tanggung jawab yang seharusnya diembannya terhadap bayinya.

Berbagai faktor yang melatarbelakangi kasus pembuangan bayi antara lain, karena permasalahan ekonomi tidak mampu untuk memenuhi kebutuhan bayinya dan berharap ada pihak yang memungut bayi tersebut, kemudian karena bayi tersebut menderita kelainan secara medis, selanjutnya untuk menutupi aib 
Jurnal Hukum Saraswati (JHS) Volume. 03, Nomor 02, (2021)

FAKULTAS HUKUM UNMAS DENPASAR

ISSN (Cetak) : 2715-758X ISSN (Online): 2720-9555

DOI:https://doi.org/10.36733/jhshs.v2i2

https://e-journal.unmas.ac.id/index.php/JHS

138

karena bayi tersebut lahir di luar penelitian hukum normatif adalah perkawinan yang sah dan karena bayi tersebut tidak diinginkan kehadirannya oleh orang tua kandungnya.

suatu proses untuk menemukan suatu aturan hukum guna menjawab isu hukum yang dihadapi. ${ }^{2}$

Hak hidup merupakan hak asasi manusia yang tentunya juga dimiliki oleh bayi sejak berada di dalam kandungan. Tidak ada seorang pun yang berhak untuk merampas hak tersebut, termasuk orang tuanya sendiri.

Berdasarkan latar belakang tersebut, penulis tertarik untuk melakukan penelitian tentang Pembuangan Bayi Dalam Perspektif Hak Asasi Manusia, dengan menggunakan analisis studi kasus yang terjadi di Propinsi Bali dalam kurun waktu tiga tahun sejak tahun 2017 sampai tahun 2020.

\section{B. Metode Penelitian}

Metode yang digunakan dalam penelitian ini adalah penelitian hukum normatif. Penelitian hukum normatif merupakan penelitian kepustakaan. Bahan hukum yang dipergunakan meliputi berbagai peraturan perundang - undangan, buku, karya ilmiah yang berkaitan dengan topik penelitian.

Menurut Peter Mahmud Marzuki,

\section{Pembahasan}

Pengaturan Hak Untuk Hidup Dalam Instrumen Internasional

Hak untuk hidup adalah hak yang paling mendasar bagi setiap manusia sebagai mahluk ciptaan Tuhan. Sifat keberadaan hak ini tidak dapat ditawar lagi (non derogable rights).Dalam pasal 3 DUHAM (Deklarasi Universal Tentang HAM) PBB menyatakan bahwa,"setiap orang mempunyai hak atas kehidupan, kemerdekaan dan keselamatannya".

Selanjutnya dalam pasal 6 ICCPR (International Covenan Civil And Political Rights) disebutkan, "setiap manusia memiliki hak untuk hidup". Hak ini harus mendapatkan perlindungan hukum. Tidak seorang pun insan manusia yang secara gegabah boleh dirampas hak untuk hidupnya.

Instrumen internasional lainnya yang mengatur yakni pasal 6 Konvensi

${ }^{2}$ Peter Mahmud Marzuki, 2010,Penelitian Hukum, Kencana Prenada, Jakarta, hlm.35 
Jurnal Hukum Saraswati (JHS) Volume. 03, Nomor 02, (2021)

FAKULTAS HUKUM UNMAS DENPASAR

ISSN (Cetak) : 2715-758X ISSN (Online): 2720-9555

DOI:https://doi.org/10.36733/jhshs.v2i2

https://e-journal.unmas.ac.id/index.php/JHS

139

Hak - Hak Anak menyatakan bahwa, hak asasi manusia warga negaranya para negara peserta konvensi mengakui bahwa tiap - tiap anak mempunyai hak tanpa terkecuali.

Menurut pasal 1 ayat (1) Undang yang melekat atas kehidupannya. undang Nomor 39 tahun 1999 tentang Setiap anak di seluruh dunia harus tetap hidup dan berkembang sebagai manusia.

Bangsa Indonesia sebagai anggota dari Perserikatan Bangsa - bangsa (PBB) mengemban tanggung jawab moral dan hukum untuk menjunjung tinggi dan melaksanakan Deklarasi Universal tentang Hak Asasi Manusia yang ditetapkan oleh PBB, serta berbagai instrumen yang telah diterima oleh Negara Republik Indonesia.

Pengaturan Hak Hidup Dalam UUD 1945 dan Undang - undang Nomor 39 Tahun 1999 Tentang Hak Asasi Manusia

Di dalam alenia pertama pembukaan Undang - undang Dasar Negara Republik Indonesia tahun 1945 tersirat bahwa Negara Indonesia adalah sebuah negara yang menjunjung tinggi hak asasi manusia. Hal ini menunjukkan bahwa bangsa Indonesia memiliki tekad untuk menjamin dan memberikan perlindungan terhadap Hak Asasi Manusia, "Hak asasi manusia adalah seperangkat hak yang melekat pada hakikat dan keberadaan manusia sebagai mahluk Tuhan Yang Maha Esa dan merupakan anugerahNya yang wajib dihormati, dijunjung tinggi dan dilindungi oleh negara, hukum, pemerintahan, dan setiap orang demi kehormatan serta perlindungan harkat dan martabat manusia. Hal ini menunjukkan bahwa hak untuk hidup sebagai bagian dari hak asasi manusia secara otomatis dimiliki oleh bayi bahkan saat masih di dalam kandungan ibunya, oleh sebab itu negara, hukum maupun setiap orang wajib untuk memberikan perlindungan terhadap hak hidup dari bayi yang baru dilahirkan.

Permasalahan tentang perlindungan terhadap hak asasi manusia tidak akan pernah ada habisnya, karena berkaitan dengan keberadaan manusia itu sendiri.

Sebagai wujud tekad dan komitmen dari Negara Indonesia terhadap penghormatan dan 
Jurnal Hukum Saraswati (JHS) Volume. 03, Nomor 02, (2021)

FAKULTAS HUKUM UNMAS DENPASAR

ISSN (Cetak) : 2715-758X ISSN (Online): 2720-9555

DOI:https://doi.org/10.36733/jhshs.v2i2

https://e-journal.unmas.ac.id/index.php/JHS

140

perlindungan hak asasi manusia warga Negara Republik Indonesia tahun 1945 negaranya, diatur dalam bentuk :

peraturan perundang - undangan dan Pasal 28A, "setiap orang berhak untuk juga dalam konstitusi yang telah hidup serta berhak mempertahankan diamandemen. Prinsip - prinsip hidup dan kehidupannya”.

tentang HAM di Indonesia, diatur Pasal 28I ayat (1), "hak untuk hidup, dalam beberapa instrumenhukum di hak untuk tidak disiksa, hak Indonesia :

1. Undang - undang Dasar Negara Republik Indonesia tahun 1945;

2. Undang - undang Nomor 39 tahun 1999 tentang Hak Asasi Manusia.Dalam undang undang ini, peraturan mengenai hak asasi manusia ditentukan dengan berpedoman pada

Deklarasi Hak Asasi Manusia, Perserikatan Bangsa - Bangsa, Konvensi Perserikatan Bangsa

- Bangsa tentang Penghapusan Segala Bentuk Diskriminasi Terhadap Wanita, Konvensi Perserikatan Bangsa - Bangsa Tentang Hak - hak Anak, dan berbagai instrumen internasional lain yang mengatur mengenai hak asasi manusia.

Pengaturan mengenai hak hidup kemerdekaan pikiran dan hati nurani, hak beragama, hak untuk tidak diperbudak, hak untuk diakui sebagai pribadi di hadapan hukum, dan hak untuk tidak dituntut atas dasar hukum yang berlaku surut adalah hak asasi manusia yang tidak dapat dikurangi dalam keadaan apapun”.Di dalam pengaturan UUD 1945 sangat jelas diatur bahwa bayi memiliki hak untuk hidup. Sebagai pihak yang lemah bayi belum mampu untuk memenuhi kebutuhan hidupnya, oleh sebab itu orang tualah yang memiliki kewajiban untuk memenuhinya, agar bayi mampu untuk mempertahankan kehidupannya. Tidak ada seorang pun yang berhak untuk mengurangi hak hidup bayi, termasuk orang tuanya sekalipun, karena hak untuk hidup merupakan hak yang melekat pada bayi dalam hakekatnya sebagai mahluk ciptaan Tuhan.

diatur dalam Undang - undang Dasar 
Jurnal Hukum Saraswati (JHS) Volume. 03, Nomor 02, (2021)

FAKULTAS HUKUM UNMAS DENPASAR

ISSN (Cetak) : 2715-758X ISSN (Online): 2720-9555

DOI:https://doi.org/10.36733/jhshs.v2i2

https://e-journal.unmas.ac.id/index.php/JHS

141

Selanjutnya dalam Undang - (2) hak anak adalah hak asasi manusia undang Nomor 39 tahun 1999 tentang dan untuk kepentingannya hak anak itu Hak Asasi Manusia, diatur sebagai diakui dan dilindungi oleh hukum berikut :

Pasal 1 angka (5), "anak adalah setiap manusia yang berusia di bawah 18 (delapanbelas) tahun dan belum menikah, termasuk anak yang masih dalam kandungan apabila hal tersebut demi kepentingannya”. Jika merujuk pada Undang - undang tentang HAM di Indonesia bayi disamakan pengertiannya dengan anak.

Pasal 4, "Hak untuk hidup, hak untuk tidak disiksa, hak kebebasan pribadi, pikiran dan hati nurani, hak beragama, hak untuk tidak diperbudak, hak untuk diakui sebagai pribadi dan persamaan di hadapan hukum, dan hak untuk tidak dituntut atas dasar hukum yang berlaku surut adalah hak asasi manusia yang tidak dapat dikurangi dalam keadaan apapun dan oleh siapapun".

Pasal 9 ayat (1), “ Setiap orang berhak untuk hidup, mempertahankan hidup dan meningkatkan taraf kehidupannya".

Pasal 52

(1)setiap anak berhak atas perlindungan oleh orang tua, keluarga, masyarakat dan negara. bahkan sejak dalam kandungan.

Pasal 53 ayat (1), “setiap anak sejak dalam kandungan, berhak untuk hidup, mempertahankan hidup, dan meningkatkan taraf kehidupannya".

Di dalam Undang - undang Nomor 39 Tahun 1999 tentang Hak Asasi Manusia sudah jelas dinyatakan bahwa bayi memiliki hak untuk hidup, dan memiliki hak untuk mendapatkan perlindungan dari orang tua, masyarakat dan negara.

Berdasarkan pasal 1 ayat Undang - undang Dasar tahun 1945 disebutkan, "Negara Indonesia adalah negara hukum". Salah satu ciri negara hukum adalah menjamin dan memberikan perlindungan terhadap hak asasi dari setiap warga negaranya. Negara dalam hal ini wajib untuk memberikan perlindungan terhadap hak asasi warga negaranya tanpa terkecuali.

Konsep perlindungan hukum merupakan salah satu hal yang sangat penting untuk dibahas pada permasalahan ini, karena fokus kajian teori ini pada perlindungan hukum 
Jurnal Hukum Saraswati (JHS) Volume. 03, Nomor 02, (2021)

FAKULTAS HUKUM UNMAS DENPASAR

ISSN (Cetak) : 2715-758X ISSN (Online): 2720-9555

DOI:https://doi.org/10.36733/jhshs.v2i2

https://e-journal.unmas.ac.id/index.php/JHS

142

yang diberikan kepada masyarakat. tersebut kemudian dibungkus plastik

Masyarakat yang menjadi sasaran pada hitam dan dibuang di lorong kos. ${ }^{4}$

teori ini adalah masyarakat yang Kasus kedua :

berada pada posisi lemah, baik dari Pada tanggal 21 Juli tahun 2019 segi ekonomi maupun dari aspek beberapa orang yang sedang yuridisnya. ${ }^{3}$ Bayi dalam hal ini berada memancing di kolam proyek Grand dalam posisi yang lemah dan wajib Sudirman di Denpasar Selatan untuk mendapatkan perlindungan secara hukum.

\section{Analisa Kasus}

Kasus pembuangan bayi di Propinsi

Bali :

Kasus pertama :

Seseorang laki - laki berinisial VKR bersama pasangannya perempuan berinisial D dibekuk oleh apparat kepolisian sebagai pelaku pembuang bayi kembar di Jalan Ratna Gang Werkudara Nomor 6, Denpasar Timur. Bayi kembar tersebut dilahirkan di kamar mandi kos VKR, setelah dilahirkan bayi kembar tersebut ditusuk dengan pisau oleh $\mathrm{D}$, tangisan bayi sempat terdengar oleh tetangga kos, namun tersangka mengelak saat ditanyakan. Mayat bayi kembar

${ }^{3}$ Salim HS., 2013,Penerapan Teori Hukum Pada Penelitian Tesis dan Disertasi, Raja Grafindo Persada, Jakarta, hlm.259

menemukan mayat bayi laki- laki yang telah membusuk. Polisi kemudian mengamankan seorang mahasiswi sebagai tersangka yang kemudian mengakui perbuatannya. Bayi tersebut dilahirkan di toilet areal kampus, karena bayi tersebut menangis tersangka beberapa kali membekap bayi tersebut dengan tangannya sampai tidak sadarkan diri dan akhirnya meninggal. Bayi tersebut dibungkus dengan jas almamater kemudian dibuang di areal kolam proyek Grand Sudirman. ${ }^{5}$

Kasus ketiga :

Pada tanggal 24 Juli 2019, Juniari melahirkan di kamar milik Sugita, mereka adalah sepasang kekasih yang belum menikah. Agar tidak diketahui

${ }^{4}$ Liputan6.com, Kelanjutan Kasus Pembuang Jasad Bayi Kembar di Bali, 26 Juli 2018, diakses 30 Juli 2021

${ }^{5}$ Kumparan.com, Panik Ditinggal Pacar, Mahasiswi Buang Bayi Hingga Tewas, 1 Agustus 2019, diakses pada tanggal 30 Juli 2021 
Jurnal Hukum Saraswati (JHS) Volume. 03, Nomor 02, (2021)

FAKULTAS HUKUM UNMAS DENPASAR

ISSN (Cetak) : 2715-758X ISSN (Online): 2720-9555

DOI:https://doi.org/10.36733/jhshs.v2i2

https://e-journal.unmas.ac.id/index.php/JHS

oleh orang lain, setelah bayi tersebut lahir, kemudian Sugita menutup mulut bayi dan kemudian mencekiknya sampai meninggal. Bayi itu kemudian dibungkus dengan handuk dan dimasukkan ke dalam tas selempang. Selanjutnya Sugita meninggalkan Juniari di kamar untuk membuang bayi tersebut di sebuah bangunan kosong di wilayah Banjar Lumbuan, Desa Sulahan Susut, Bangli.

Dari ketiga kasus di atas terlihat bahwa pembuangan bayi justru dilakukan oleh orang tua kandung dari bayi tersebut. Sebelum dibuang bayi tersebut dibunuh terlebih dahulu. Sangat ironis sekali, dimana hati nurani dari seorang ibu, dengan teganya membunuh darah dagingnya sendiri, kemudian membuangnya seperti seonggok sampah. Hak hidup yang dimiliki oleh bayi tersebut, dirampas oleh orang tuanya sendiri.

Sejak bayi dilahirkan telah melekat hak hidup yang merupakan hak asasi manusia sebagai mahluk ciptaan Tuhan. Setiap orang wajib untuk menghormati dan melindungi, tanpa terkecuali orang tuanya sendiri. Tidak ada seorang pun yang dapat merampas hak hidup dari bayi yang baru dilahirkan.

Melihat banyaknya kasus yang terjadi dalam kurun waktu tiga tahun terakhir, terlihat tidak adanya efek jera bagi pelaku kejahatan pembuangan bayi. Pelaku pada umumnya tidak dihukum sebagai pelaku pelanggaran Hak Asasi Manusia.

Sebagai implementasi penghormatan dan perlindungan terhadap hak hidup bayi,sudah seharusnya pelaku ditindak secara tegas sebagai pelaku pelanggaran Hak Asasi Manusia. Tidak tegasnya penindakan terhadap pelaku pelanggaran Hak Asasi Manusiapada bayi merupakan sebuah pembiaran terhadap adanya perampasan hak hidup seseorang.

Sesuai dengan amanat dari UUD 1945 dan Undang - undang Nomor 39 Tahun 1999 tentang Hak Asasi Manusia, Indonesia merupakan sebuah negara yang memiliki tekad dan komitmen untuk menjamin dan memberikan perlindungan terhadap hak asasi dari setiap warga negaranya.

Seharusnya kasus pembuangan bayi ini mendapatkan perhatian yang serius dari negara, pemerintah maupun 
Jurnal Hukum Saraswati (JHS) Volume. 03, Nomor 02, (2021)

FAKULTAS HUKUM UNMAS DENPASAR

ISSN (Cetak) : 2715-758X ISSN (Online): 2720-9555

DOI:https://doi.org/10.36733/jhshs.v2i2

https://e-journal.unmas.ac.id/index.php/JHS

144

masyarakat pada umumnya. Sampai kapan kita akan membiarkan banyak bayi yang dilahirkan akhirnya dibunuh dan dibuang oleh orang tua kandungnya. Kerjasama antara masyarakat dan pemerintah sangat diperlukan dalam kondisi seperti ini.

Urgensi terhadap pengaturan instrumen hukum yang tepat sangat diperlukan dalam memberikan efek jera kepada pelaku kejahatan pembuangan bayi. Pada umumnya pelaku pembuangan bayi dihukum sebagai pelaku tindak pidana penelantaran maupun pembunuhan terhadap bayinya. Sebagai bentuk penegakan hak asasi manusia yang dimiliki oleh bayi, sudah seharusnya pelaku dihukum sebagai pelaku pelanggaran terhadap hak asasi manusia.

\section{Simpulan dan Saran}

Sejak di dalam kandungan bayi sudah memiliki hak untuk hidup, dimana hak untuk hidup ini merupakan hak asasi manusia sebagai mahluk ciptaan Tuhan. Hak ini bersifat tidak dapat ditawar lagi (non derogable rights). Tidak ada seorang pun yang dapat mengabaikan dan merampas hak tersebut.

Penerapan sanksi pidana terhadap pelaku tindak kejahatan pembuangan bayi selama ini kurang efektif, hal ini dapat dilihat semakin meningkatnya kasus pembuangan bayi di Propinsi Bali dalam kurun waktu 3 (tiga) tahun terakhir.Tidak ada efek jera bagi pelaku pembuangan bayi.Pendekatan secara sosial hendaknya ditekankan, dalam hal ini keluarga dan lingkungan sangat memegang peranan penting.

Sebagai bentuk penghormatan terhadap hak hidup yang dimiliki oleh bayi, hendaknya penegakan hukum dalam konteks hak asasi manusia dalam hal ini hak untuk hidup yang direnggut, ke depannya dapat diproses sebagai bentuk kejahatan atas pelanggaran hak asasi manusia melalui pengadilan HAM. Instrumen hukum yang tepat diperlukan untuk memberikan efek jera kepada pelaku kejahatan pembuangan bayi.

\section{Daftar Pustaka}

\section{Buku}

Peter Mahmud Marzuki, 2010,Penelitian Hukum, Kencana Prenada, Jakarta. 
Jurnal Hukum Saraswati (JHS) Volume. 03, Nomor 02, (2021)

FAKULTAS HUKUM UNMAS DENPASAR ISSN (Cetak) : 2715-758X ISSN (Online): 2720-9555

DOI:https://doi.org/10.36733/jhshs.v2i2 https://e-journal.unmas.ac.id/index.php/JHS

Salim HS., 2013, Penerapan Teori

Hukum Pada Penelitian Tesis dan

Disertasi, Raja Grafindo Persada, Jakarta.

\section{Internet}

Tribunnews.com, 2020, Tercatat 40 Kasus Pembuangan Bayi di Bali, Yang Anyar Ditemukan di Sungai Badung, diakses pada tanggal 30 Juli 2021

Liputan6.com, Kelanjutan Kasus Pembuang Jasad Bayi Kembar di Bali, 26 Juli 2018, diakses 30 Juli 2021

Kumparan.com, Panik Ditinggal Pacar, Mahasiswi Buang Bayi Hingga Tewas, 1 Agustus 2019, diakses pada tanggal 30 Juli 2021

\section{Peraturan Perundang-Undangan}

Undang - undang Dasar Negara

Republik Indonesia Tahun 1945

Undang-Undang Republik Indonesia Nomor 39 Tahun 1999 Tentang Hak Asasi Manusia. Lembaran Negara Republik Indonesia Tahun 1999 Nomor 165. 